\title{
THE LEVEL OF KNOWLEDGE OF THE RURAL PEOPLE ON THE ECOLOGICAL AND BIOLOGICAL ASPECTS OF THE RED FOX (Vulpesvulpes) IN SHARYA COMPLEX IN DUHOK GOVERNORATE IN KURDISTAN OF IRAQ ABSTRACT:
}

\author{
HASSAN KHERZI ALI ${ }^{*}$ and AMIN ABDO KHEDHER ${ }^{* *}$ \\ *Dept. of Forestry, College of Agricultural Engineering Sciences, University of Duhok, \\ Kurdistan Region-Iraq. \\ *** Dept. of Recreation and Ecotourism, College of Agricultural Engineering Sciences, \\ University of Duhok, Kurdistan Region-Iraq.
}

(Received: March 16, 2021; Accepted for Publication: May 18, 2021)

\begin{abstract}
The success of the development process requires the integration of its components of conscious human elements and material support, and given the importance of Rural people knowledge in all areas of knowledge, especially those related to the environmental and biological aspects of the red foxes (Vulpes vulpes), which are the focus of the current research due to their great impacts on the fields of farmers and rural people. This research aimed to identify the level of knowledge of the rural people about the ecological and biological information aspects of the red foxes in the (Sharya) complex, and the identification of the correlation between the level of the level of knowledge on the environmental and vital aspects of the red foxes as dependent variables and each of the following independent variables (age, gender, current occupation, educational level, and place of residence). A simple random sample of 126 was chosen representing $25 \%$ of the study population, with the exception of the pilot sample (30), via a special questionnaire form consisting of two parts, the first of which is related to the independent variables, the second includes a test consisting of 17 items distributed in two domains (environmental and biological).After ensuring their Face and content validity and validity of their contents, a consistency was measured by the Cuder Richardson method, followed by data collection and it was unpacked, categorized and statistically treated using a number of statistical methods. Due to the normal distribution of the data, Frequencies, Averages, Percentages, Spearman Correlation Coefficient, and Correlation Coefficient Pearson were used to analyze the data. This study revealed that, the level of knowledge of the rural people in the Sharya collective town is Medium in environmental and vital aspects with a percentage $(61.9 \%)$ and $(53.2 \%)$, respectively, and the study did not show a correlation between the level of Knowledge and the following factors: (age, place of residence, and current profession), while the study showed a correlation between the level of Knowledge and (educational level, and gender).
\end{abstract}

KEYWORDS: Red Fox, Shariya Complex, Ecological Information, Biologicl Information, Vulpes vulpes

\section{INTRODUCTION}

A $\mathrm{s}$ a consequence of increasing humanwildlife encounters, the associated potential for human-wildlife conflict rises. Taking the human dimension of wildlife management into account is very necessary in wildlife conservation. Rather than this scientific workers in this field need to understand how people perceive wildlife, (Sophia et al.2020). Almost all natural habitats worldwide are subject to human encroachment, which increases the level of shared human-wildlife living space and creates potential for human-wildlife conflict.
Generally, implications of human-wildlife coexistence may be social, economic, or healthrelated and both actual and assumed implications may have a large impact on the acceptance of wildlife by the general public (Decker et al.2012).Therefore, many conservationists propose that considering the social, physical, and economic well-being of people is central to a holistic conservation approach (Minteer\& Miller, 2011). Wildlife acceptance by humans is a crucial element of modern conservation and wildlife management (Greving\&Kimmerle, 2020). 
Social psychological and philosophical explanatory variables, such as environmental attitudes, ethical positions, biophilic factors, and social norms, have proven to be superior predictors of the willingness-to-pay (WTP) than those of socio-economy (Spashet al., 2009).This fact has become clear to environmental sociologists and economists in recent decades, yet it has not been fully integrated in the fields of conservation biology and wildlife management (Ojea\&Loureiro, 2007). As a consequence, researchers, conservation agents, wildlife managers, and policy makers aim to raise awareness for the inherent value of biodiversity and to increase wildlife tolerance (Decker et al. 2016). Saunders, Brook, and (Myers2006).Red foxes (Vulpesvulpes) are potential predators of poultry and a threat to smaller companion animals and they cause damages in public and private gardens. Since attitudes toward foxes therefore vary from very negative to extremely positive, this species is well suited for assessing how these attitudes are influenced by people's backgrounds. Urbanization, the process by which rural or natural areas are converted to urban and suburban environments, is one of the most rapid and influential human activities ever undertaken (Collins et al. 2000).

To best prepare communities, one first must understand the knowledge, attitudes, and opinions of the individuals within communities responsible for making decisions and implementing those decisions, (Elsner2008).Human-wildlife conflict occurs "when the needs and behavior of wildlife impact negatively on the goals of humans or when the goals of humans negatively impact the needs of wildlife" (Madden 2004). Negative impacts on human goals generally result when stakeholders' wildlife acceptance capacity (WAC: defined as the wildlife population level in an area that is acceptable to people [Decker \& Purdy 1988) has been exceeded.

The behavior of the red fox varies according to the different environments it inhabits, (David \& Claudio, 2004) demonstrated that any two different populations of red foxes can behave so differently that they are two different species. The red fox is active at dusk as a whole and tends to be nocturnal in areas where human activity is abundant, such as inhabited areas with electric lighting, and the red fox is a solitary hunter, and in the event that it hunts a number of game that exceeds its need, it will store the excess food in pits in the ground to eat it later (Macdonald, 2004). Because of the danger of foxes on farmers' fields, especially poultry fields, and the fact that the area North and South Sharya complex is famous for the presence of red foxes, so the study was conducted to identify the level of their Knowledge of the environmental and biological, so the problem of the study is limited to the answer to The following questions:

1. What is the level of Knowledge of the rural people on the environmental and biological information aspects of the red foxes?

2. What is the relationship between the level of Knowledge of the rural people with aspects of the environmental and biological information of the red foxes as a dependent variable and each of the following independent variables (gender, upbringing, and the number of family members)?

\section{MATERIALS AND METHODS}

\subsection{Sample and population:}

In light of the statistics taken from the Urban Planning Department in Duhok Governorate, three areas located in (Sharya) complex were chosen. The research Sample included (126) rural residents out of a total of (534), representing about (25\%) of the research population, after excluding (30) individuals for measuring the stability of the questionnaire.

\subsection{Data collection:}

Data were collected using questionnaires through a personal interview. The questionnaires included two parts: The first part includes independent factors (age, gender, current occupation, educational level, and the place of residence), as these independent factors were determined after reviewing the relevant literatures and reviewing some studies related to the subject of research in addition to consulting specialists in Agricultural Extension Department.

\subsection{Measuring independent variables:}

The independent variables related to the research topic were measured as follows: (age, gender, current occupation, educational level, and place of residence).

Age: It was measured by asking the respondent about age in years.

Gender: It was measured according to two levels (male, female) and the following weights were given (1 and 2), respectively. 
Current occupation: it was measured from three levels (earner, employee, farmer) and the following weights were given $(1,2,3)$, respectively.

Place of residence: it was measured according to two levels (city, countryside, suburb) and the following weights were given $(1,2,3)$, respectively.

Educational level: It was measured according to the following levels: (illiterate, reading and writing, elementary, intermediate, preparatory, diploma, bachelor's, and graduate degree) and these levels were given the following weights: $(1,2,3)$ respectively. As for the second part of the questionnaire, it aimed to measure the level of Knowledge of the rural population on the environmental and vital aspects of the red foxes in the (Sharya) complex, through a multiple-choice test, and it included two aspects:

the first: environmental information (7) paragraphs, the second: vital information (10) items. A multiple choice test was used, and a score of (0) for the wrong answer and (1) for the correct answer was given. And the total numerical values of the test are (17) numeric values, so that the test values are limited to the level of knowledge between (0-17) numeric values. The researcher presented it to a number of specialists in the psychological, educational and extension sciences and the Forestry Department, and in general the paragraphs were agreed upon with some amendments that included the addition and the linguistic correction and thus the form became ready for the pretest. Then a pretest was conducted on a pilot sample of (30) individuals from Sharya complex in December (2019) and followed the Coder Richardson method for measuring stability. The value of the stability factor was (76\%) and to know its validity factor, it was calculated by the root of the stability factor, which reached a value of $(0.87 \%)$. Then, the data collection phase followed, then collected and classified electronically, and conducting statistical treatments on them, using each of (percentages, arithmetic mean, standard deviation, simple correlation coefficient, Pearson coefficient and coefficient of rank correlation by Spearman Brown. This is because the data follows the normal distribution according to the Tests of Normality, and SPSS program used to analyze the data

\section{RESULTS AND DISCUSSION} 3.1. Identifying the level of Knowledge of the rural People regarding the environmental information aspects of red foxes in (Sharya) complex.

The success of biological conservation initiatives is not solely reliant on the collection of ecological information, but equally on public adherence to protection programs. Awareness and perception of target species condition the intensity and orientation of public involvement in conservation initiatives. Their evaluation is critical in the case of elusive animals, for which incertitude surrounding public attitude is maximized, (Christian Ernest et al., 2015).

The results of the study showed that the highest theoretical numerical value that the respondent can obtain is (7) degrees and the lowest value is (0), with an arithmetic mean of (1.847) degrees and a standard deviation of (1.202) degrees The level of knowledge of the rural People regarding the environmental information aspects of the red foxes In Sharia complex was classified into three categories as shown in Table (1). Moreover about $(61.9 \%)$ of the respondents People have a medium level of knowledge, as shown in table (1). The reason for this may be due to the presence of the respondents near the territory of foxes, so they will be aware of most environmental information, especially as they live in villages and those areas where foxes are abundant. 
Table (1): The level of Knowledge of the rural population regarding the environmental information aspects

\begin{tabular}{cccc}
\hline Knowledge degree & $\begin{array}{c}\text { Number of } \\
\text { respondents }\end{array}$ & \%percentage & $\begin{array}{c}\text { Average value of knowledge } \\
\text { awareness }\end{array}$ \\
\hline$(1-2)$ weak & 20 & 15.9 & 1.321 \\
\hline$(3-4)$ intermediate & 78 & 61.9 & 5.564 \\
\hline$(5$ and over $)$ high & 28 & 22.2 & \\
\hline Total & 126 & 100 & \\
\hline
\end{tabular}

Environmental attitude has been shown to be an indicator of support for wildlife conservation (Sharp et al., 2011) and one of the leverage points for successful policies (Zinn et al., 1998).
It is clear from Table (2) that the Item that ranked first is the paragraph (Where does the fox live?) due to the high information that they live in the mountains, as shown in Table (2).

Table (2): The order of knowledge items regarding aspects of Ecological information

\begin{tabular}{|c|c|c|c|c|c|c|c|}
\hline \multirow[t]{2}{*}{ No. } & \multirow[t]{2}{*}{ Ecological information } & \multicolumn{2}{|c|}{ Correct answer } & \multicolumn{2}{|c|}{ Incorrect answer } & \multirow[t]{2}{*}{ Arithmetic mean } & \multirow[t]{2}{*}{ Rank } \\
\hline & & No & $\%$ & No & $\%$ & & \\
\hline 1 & Where do red foxes live? & 111 & 88.1 & 15 & 11.9 & 0.881 & 1 \\
\hline 2 & $\begin{array}{l}\text { If this species loves agricultural lands, then what variety } \\
\text { does prefer the most? }\end{array}$ & 67 & 53.2 & 59 & 46.8 & 0.468 & 4 \\
\hline 3 & $\begin{array}{l}\text { If the categories in the Q2 got the priority, give reason for } \\
\text { that. }\end{array}$ & 22 & 17.5 & 104 & 82.5 & 0.175 & 7 \\
\hline 4 & Which climate do red fox favor? & 56 & 44.4 & 70 & 55.6 & 0.444 & 6 \\
\hline 5 & Which plant density does the fox prefer the most? & 68 & 54 & 58 & 46 & 0.460 & 5 \\
\hline 6 & Where do fox burrows exist? & 89 & 70.6 & 37 & 29.4 & 0.706 & 2 \\
\hline 7 & How many openings do the fox burrows have? & 65 & 51.6 & 61 & 48.4 & 0.516 & 3 \\
\hline
\end{tabular}

3.2. Identify the level of Knowledge of the rural population on the vital information aspects of the red foxes in (Sharya) complex.

Studies on perceptual factors are important for the case of elusive species like the fox in our study, in which uncertainty surrounding potential explanatory variables (e.g. awareness, knowledge, and affect) exists. To date elusive animals have received limited attention in the literature (Oliet al.1994).

The results of the study showed that the highest theoretical numerical value that the respondent can obtain is (10) degrees and the lowest value (0), with an arithmetic mean of
(4.412) degrees and a standard deviation of $(3,650)$ degrees. The level of Knowledge of the rural population regarding the vital information aspects of the red foxes in Sharya complex was classified into three categories depending on the theoretical extent, as shown in Table (3). Which shows that around (67) of the respondents have an average level of knowledge, and the highest percentage was $(53.2 \%)$. This may be due to the presence of the respondents in mountainous rural residential areas, so they would be close to the life of foxes and their behaviors, which was reflected in their information.

Table (3): The level of Knowledge of the rural population on aspects of vital information in (Sharya)

\begin{tabular}{lccc}
\hline Knowledge degree & $\begin{array}{l}\text { Number of } \\
\text { respondents }\end{array}$ & percentage\% & $\begin{array}{l}\text { Average value of knowledge } \\
\text { awareness }\end{array}$ \\
\hline$(1-3)$ low & 43 & 34.1 & 1.321 \\
\hline$(4-6)$ intermediate & 67 & 53.2 & 3.564 \\
\hline 7 and over, highest & 16 & 12.7 & 5.521 \\
\hline Total & 126 & 100 & \\
\hline
\end{tabular}

It is shown from Table (4) that the item that ranked first is the Item (How many years does a fox live?) by virtue of the presence of foxes in the villages and fields of the population, so that 
they are aware of the nature of their lives and their ages, as shown in Table (4).

Table (4): The ranked of knowledge items regarding Biological information aspects

\begin{tabular}{|c|c|c|c|c|c|c|c|}
\hline \multirow[t]{2}{*}{ No. } & \multirow[t]{2}{*}{ Statements } & \multicolumn{2}{|c|}{$\begin{array}{c}\text { Correct } \\
\text { answers }\end{array}$} & \multicolumn{2}{|c|}{ Wrong answers } & \multirow[t]{2}{*}{$\begin{array}{c}\text { Arithmetic } \\
\text { mean }\end{array}$} & \multirow[t]{2}{*}{ Rank } \\
\hline & & No. & $\%$ & No. & $\%$ & & \\
\hline 1 & Which one of these carnivores a fox looks like? & 74 & 58.7 & 52 & 41.3 & 0.587 & 4 \\
\hline 2 & Which one of these carnivores a fox sound looks like? & 103 & 81.7 & 23 & 18.3 & 0.190 & 10 \\
\hline 3 & Where does the fox sleep in winter? & 27 & 21 & 99 & 78.6 & 0.294 & 8 \\
\hline 4 & Where does the fox sleep in the summer? & 83 & 65.9 & 43 & 34.1 & 0.357 & 7 \\
\hline 5 & When do red fox mate? & 92 & 73 & 34 & 27 & 0.270 & 9 \\
\hline 6 & When do red fox born? & 56 & 44.4 & 70 & 55.6 & 0.460 & 5 \\
\hline 7 & How many years is the life span of red fox? & 68 & 54 & 58 & 46 & 0.659 & 1 \\
\hline 8 & How many days is the gestation of red foxes? & 55 & 43.7 & 71 & 56.3 & 0.437 & 6 \\
\hline 9 & How high is a red fox? & 71 & 56.3 & 55 & 43.7 & 0.563 & 2 \\
\hline 10 & How many litters can has a red fox? & 76 & 60.3 & 50 & 39.7 & 0.595 & 3 \\
\hline
\end{tabular}

3.2.1. Determine the correlation between the level of Knowledge of the rural People with the environmental and biological information aspects of the red foxes in the (Sharya) complex as a dependent variable and each of the following independent variables (age, gender, current occupation, educational level, and the place of residence) .

However, (Sophia 2020), detected that, wildlife perception is affected by various factors. So understanding the factors affecting wildlife perception is crucial for environmental communication and for fostering acceptance of conservation measures to improve conservation strategies.

\subsubsection{Age}

The respondents were divided into three categories depending on the range and length of the category, as the highest numerical value was (71) years old and the lowest age for the respondents was (18) years, as shown in Table (5), It was found that there are differences in the average value of the level of Knowledge for the three groups, as it became clear that the older the respondents and as a result of their increased knowledge of environmental and biological information related to red foxes, To find the correlation between the subjects' knowledge awareness level and age, the Pearson correlation coefficient was used, with its value (0.061), which is a non-significant value at the probability level (0.05), meaning that there is no correlation between the two variables. Relevant to this study (Sophia 2020), found a negative correlation between age and the risks perceived regarding foxes.

\subsection{2 gender}

The results in Table (5), showed that more than two-thirds of the respondents were males, as they accounted for $(62.7 \%)$ of the total respondents. To find the correlation between the respondents' knowledge awareness level and the gender variable, the ranks correlation coefficient was used, with a value of $(0.381 * *)$, which is a significant value at a probability level of (0.01).That is, there is a correlation between the two variables, and the reason for this may be due to the preoccupation of the majority of the respondents who live in areas where the red foxes are present, which makes them closer to them as well as their presence at work outside the home, which makes them close to reality. These results agree with those of (Sophia 2020), which found in his studies, that men held a more positive attitude and perceived less risk than women.

\subsubsection{Current Occupation:}

It is evident from Table No. (5) that the respondents work as a gainful profession, as their percentage reached $(80.2 \%)$, and to find the correlation between the level of knowledge of the respondents and the variable of the current profession, the ranks correlation coefficient was used as it reached (0.100), which is a nonsignificant value at the probability level (0.05).There is no correlation between the two variables. However, (Sophia 2020), found in their scientific work, that perceived risks 
decreased with participants' general life satisfaction.

\subsubsection{Educational level}

The wildlife management profession is currently being expanded to include not only the scientific expertise of biologists, but also the values and attitudes of the public that have an interest in the wildlife being managed (Decker et al. 1992). The inclusion of such 'human dimensions' in wildlife management planning is particularly important in urban areas where the potential for human-wildlife interaction and conflict is increased (Murphy1988). Agencies and planners have realized that the ecological and behavioral knowledge essential for the development of effective management plans is extremely limited or even nonexistent (Jones 2003). The general community can be a valuable source of information regarding the presence and abundance of local wildlife (Lunneyet al. 2000). Community wildlife surveys can also serve to provide the public with an opportunity to express their opinions and concerns regarding the presence of local wildlife. The importance of incorporating public opinion and values into wildlife management decisions is being increasingly recognized in various fields of environmental science (Miller \& McGee 2001).

It is crucial to know which factors shape human perception of wildlife, that is, the knowledge about certain wildlife species, perception of the risks associated with these species, and the attitudes toward them. Since a higher formal level of education usually goes along with greater general knowledge (Conway, Cohen, \& Stanhope, 1991).

The results of the research, as shown in Table (5), showed that $34.1 \%$ do not know how to read and write, which is the largest percentage. To find the correlation between the knowledge awareness level and the educational level variable, the ranks correlation coefficient was used, with its value $(0.576 * *)$, which is a significant value at the probability level (0.01), meaning that there is a correlation relationship between the two variables.

\subsubsection{Place of residence:}

The results indicated as shown in Table No. (5), that the majority of the respondents lived in the village, where their percentage reached $(99.2 \%)$ of the total respondents. To find the correlation between the level of knowledge awareness and the variable of residence, Spearman's correlation coefficient was used, which reached a value of (0.066), which is a non-significant value. No correlation found between the two variables. While, (Sophia et al., 2020), indicated in their results that people who live in rural areas perceived higher risks regarding foxes and showed a less positive attitude than people in urban or suburban areas. Rather than this they added that people who perceived higher risks and held a less positive attitude supported lethal population management actions more often. The public's knowledge and understanding of basic wildlife biology and life history have decreased as fewer and fewer members of society possess prior experience living in rural environments or in close proximity to wildlife (Adams et al. 2006). Rather than this, different authors indicated that, suburban areas offer foxes an ideal habitat $\begin{array}{lll}\text { (Contesseet al. 2004). } & \text { al }\end{array}$ 
Table (5): shows the correlation between the level of Knowledge of rural people on environmental and biological information aspects of the red foxes in (Sharya) complex and each of the independent variables.

\begin{tabular}{|c|c|c|c|c|}
\hline Variables & frequency & $\%$ & $\begin{array}{l}\text { The average value of } \\
\text { knowledge awareness }\end{array}$ & Correlation coefficient \\
\hline \multicolumn{5}{|l|}{ Age } \\
\hline Age(18-35) & 88 & 69.8 & 10.435 & \multirow{3}{*}{$\begin{array}{c}\text { 0.061Pearson Correlation } \\
\text { Coefficient }\end{array}$} \\
\hline Age(36-53) & 33 & 26.2 & 12.543 & \\
\hline Age(54-71) & 5 & 4 & 14.235 & \\
\hline \multicolumn{5}{|l|}{ Gender } \\
\hline Male & 79 & 62.7 & 14.764 & \multirow{2}{*}{$\begin{array}{l}\text { Spearman Brown }{ }^{* *} 0.381 \\
\text { correlation coefficient }\end{array}$} \\
\hline Female & 47 & 37.3 & 10.542 & \\
\hline \multicolumn{5}{|l|}{ Residence } \\
\hline Village & 125 & 99.2 & 14.251 & \multirow{3}{*}{$\begin{array}{c}\text { Pearson Correlation } 0.066 \\
\text { Coefficient }\end{array}$} \\
\hline Town & 0 & 0 & 0 & \\
\hline Individual farm & 1 & 0.8 & 9.321 & \\
\hline \multicolumn{5}{|l|}{ Education level } \\
\hline Analphabet & 43 & 34.1 & 10.134 & \multirow{8}{*}{$\begin{array}{c}\text { Spearman - Brown }{ }^{* *} 0.576 \\
\text { correlation coefficient }\end{array}$} \\
\hline Can read \& write & 22 & 17.5 & 11.271 & \\
\hline Primary school & 3 & 2.4 & 11.732 & \\
\hline Intermediate school & 14 & 11.1 & 11.621 & \\
\hline Secondary school & 30 & 23.8 & 12.823 & \\
\hline Diploma & 7 & 5.6 & 13.761 & \\
\hline BSc & 6 & 4.8 & 14.631 & \\
\hline Higher level & 1 & 0.7 & 15.286 & \\
\hline \multicolumn{5}{|l|}{ Occupation } \\
\hline Officer & 15 & 11.9 & 12.436 & \multirow{3}{*}{$\begin{array}{l}\text { Spearman - Brown } 0.100 \\
\text { correlation coefficient }\end{array}$} \\
\hline Labor & 101 & 80.2 & 10.653 & \\
\hline Farmer & 10 & 7.9 & 14.521 & \\
\hline
\end{tabular}

\section{CONCLUSIONS}

The level of knowledge of the rural people on the ecological and biological aspects of red foxes is generally medium. There is a significant correlation between knowledge level of the rural population on the ecological and biological aspects of red foxes with gender and educational level.The variation in the opinions of the rural population about red foxes according to their top answer, and it was found that the percentage of their vision of the foxes is $(25.4 \%)$ and that the foxes are not desirable because they have no value by $(71.4 \%)$ and that the foxes are desirable because they are useful by (52.4\%) and they do not like the foxes by $(85.7 \%)$ because they are clean the nature from dead animals and is $(93.7 \%),(81 \%)$ hate it because they smell foul, $(92.9 \%)$ of the respondents killed foxes with firearms, $(90.5 \%)$ of the subjects were injured in the heart, (94.4\%) did not catch foxes with traps, and $(99.2 \%)$ used poisonous baits. In addition to that $(56.3 \%)$ shocked foxes with cars, and $(59.5 \%)$ of respondents let foxes die without their help if they see them wounded in front of them. The size of the challenge that will face farmers in the future if we leave foxes without scientific management is small. Foxes harm the residential site by causing many accidents on the roads, $(80.2 \%)$. Foxes affect smaller predators'morethan native predators in the region, at (64.3\%). The methods used to reduce the damage of foxes in the area were hunting by $(43.7 \%)$.

\section{REFERENCES}

Adams, C. E., K. J. Lindsey, and S. J. Ash. (2006). Urban Wildlife Management.CRC Press, Boca Raton, Florida, USA.

Aldrich, G. A., Grimsrud, K. M., Thacher, J. A., \& Kotchen, M. J. (2007). Relating environmental attitudes and contingent $\mathrm{v}$ alues: how robust are methods for identifying preference heterogeneity? Environmental and Resource Economics, 37(4), 757-775.

Al-Nabhan, Musa, (2004).Measurement Methods in the Behavioral Sciences, Dar Al Shorouk

for Publishing and Distribution, Amman, Jordan. Christian Ernest Vincenot, Anja Maria Collazo, and Kristy WallmocLina Koyama, 2015.

Public awareness and perceptual factors in the conservation of elusive species: The case of the endangered Ryukyu flying fox. GlobalEcologyandConservation 3

(2015)526-540. 
Collins, G. H. and Ingwersen, K. (2000). Paralysis tick research. Australian Veterinary Journal 78, 311.

Contesse P, Hegglin D, Gloor S, Bontadina F,Deplazes P (2004) The diet of urban foxes (Vulpesvulpes) and the availability of anthropogenic food in the city of Zurich, Switzerland. MammBiol 69:8195.

Conway, M. A., Cohen, G., \& Stanhope, N. (1991). On the very long-term retention of knowledge acquired through formal education: Twelve years of knowledge psychology. Journal of Experimental Psychology: General, 120, 395- 409.

David, MacDonald and Claudio CeleroZebiri, 2004.The Biology and Conservation of Wild Canidae.University Press.ISBN 0198-51556-1.

DOI:10.1093/acprof:oso/9780198515562. 001.0001.

Decker DJ, Chase LC (1997) Human dimensions of living with wildlife - a management challenge for the 21 st century. WildlSoc Bull 25:788-795

Decker, D. J., and K. G. Purdy. 1988. Toward a concept of wildlife acceptance capacity in wildlife management. Wildlife Society Bulletin 16:53-57.

Decker, D. J., Brown, T. L., Connelly, N. A., Enck, J. W., Pomerantz, G. A., Purdy, K. G. andSiemer, W. F. (1992). Toward a Comprehensive Paradigm of Wildlife Management: Integrating the Human and Biological Dimensions. In 'American Fish and Wildlife Policy: The Human Dimension'. (Ed. W. R. Mangun) (Southern Illinois University Press: Carbondale.

Decker, D. J., Siemer, W. F., Evensen, D. T. N., Stedman, R. C., Mccomas, K. A., Wild, M. A., ... Leong, K. M. (2012). Public perceptions of wildlife-associated disease: Risk communication matters. HumanWildlife Interactions, 6, 112- 122.

Decker, D., Smith, C., Forstchen, A., Hare, D., Pomeranz, E., Doyle-Capitman, C., Organ, J. (2016). Governance principles for wildlife conservation in the $21 \mathrm{st}$ century. Conservation Letters, 9, 290295.

Elsner, R. M. (2008). Knowledge, attitudes, and opinions about human-wildlife conflicts held by community leaders in Virginia (Doctoral dissertation, Virginia Tech).
Friday, Jamal (2020), The Scientific Committee of the Arab Union for Sustainable Development and the Environment, Wild Animals, Al-Bawaba News Newspaper.

Greving, H., \&Kimmerle, J. (2020). Better to be informed: Threatening bats increase recall of information. Human Dimensions of Wildlife, 25(1), 94- 99.

Jones, D. N. (2003). Contemporary urban ecology: the view from the Antipodes. In '4th International Conference on Ecosystems and Sustainable Development'. Siena, Italy. (EdsE. Tiezzi, C. A.Brebbia and J. L. Uso) pp. 745-753.

Knight, A. J. (2008). "Bats, snakes and spiders, Oh my!" How aesthetic and negativistic attitudes, and other concepts predict support for species protection. Journal of Environmental Psychology, 28(1), 94-103.

König A (2005) eueUntersuchungsergebnissezur Ausbreitung des KleinenFuchsbandwurms (Echinococcusmultilocularis) im GroßraumMünchen. In: Wissenschaften Bayer. Akademie d. (ed) Rundgespräche der KommissionfürÖkologie, Band 29: Zur Ökologie von Infektionskrankheiten: Borreliose, FSME und Fuchsbandwurm. Verlag Dr. Friedrich Pfeil, München, pp $71-\quad 84$.

Krausmann P (2002) Introduction to wildlife management.Pearson Education, Upper Saddle River, NJ.

Lunney, D., O'Neill, L., Matthews, A. and Coburn, D.(2000). Contribution of community knowledge of vertebrate fauna to management and planning: a case study on the Iluka Peninsula, north coast New South Wales. Ecological Management and Restoration 1, 175-184.

Madden, F. (2004). Preventing and mitigating human-wildlife conflicts: World Parks Congress recommendation. Human Dimensions of Wildlife 9:259-260.

Martín-López, B., Montes, C., \&Benayas, J. (2007).The non-economic motives behind the willingness to pay for biodiversity conservation. Biological conservation, 139(1- 2), 67-82.

Miller, K. K. and McGee, T. K. (2001).Toward incorporating human dimensions information into wildlife management decision-making. Human Dimensions of Wildlife 6, 205-221. 
Miller, T. R., Minteer, B. A., \& Malan, L. C. (2011).The new conservation debate: The view from practical ethics. Biological Conservation, 144, 948-957.

Murphy, D. D. (1988). Challenges to biological diversity in urban areas.In 'Biodiversity'.(Eds E. O. Wilson and F. M. Peter) pp. 71-76. (National Academy Press: Washington.)

Ojea, E., \&Loureiro, M. L. (2007).Altruistic, egoistic and biosphericvalues in willingness to pay (WTP) for wildlife. Ecological Economics, 63(4), 807-814.

Oli, M. K., Taylor, I. R., \& Rogers, M. E. (1994).Snow leopard Panthera uncia predation of livestock: an assessment of local perceptions in the Annapurna Conservation Area, Nepal.

Biological Conservation, 68(1), 63-68.

Salafsky, N. (2011). Integrating development with conservation. A means to a conservation end, or a mean end to conservation? Biological Conservation, 144, 973-978.
Saunders, C., Brook, A., \& Myers, O. (2006).Using psychology to save biodiversity and human wellbeing.Conservation Biology, 20(3), 702705.

Sophia E. Kimmig, Danny Flemming, Joachim Kimmerle, Ulrike Cress and Miriam Brandt, (2020).Elucidating the sociodemographics of wildlife tolerance using the example of the red fox (Vulpesvulpes) in Germany.Conservation Science and Practice. Volume 2, Issue 7 e212.

Spash, C. L., Urama, K., Burton, R., Kenyon, W., Shannon, P., \& Hill, G. (2009). Motives behind willingness to pay for improving biodiversity in a water ecosystem: Economics, ethics and social psychology. Ecological Economics, 68(4), 955-964.

Zinn, H. C., Manfredo, M. J., Vaske, J. J., \&Wittmann, K. (1998).Using normative beliefs to determine the acceptability of wildlife management actions. Society \&Natural Resources, 11(7),649-662.

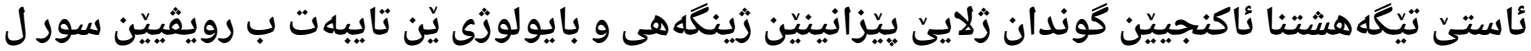

\section{كومهلكَه ها شارييا}

يوخته

سهركه فتنا كريارا وراركرنى ييتقى هندهك بنهرهتين يِيّكه فتييّن ز هيّزا مروفايهتيا تيّكه هشتى و

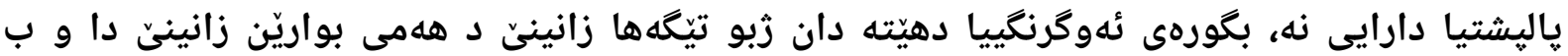

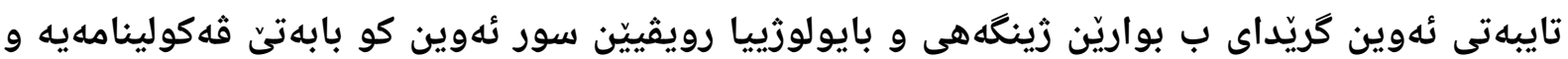

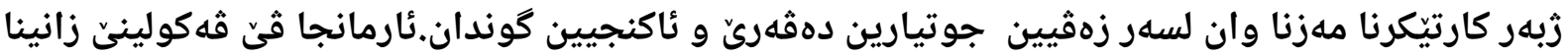

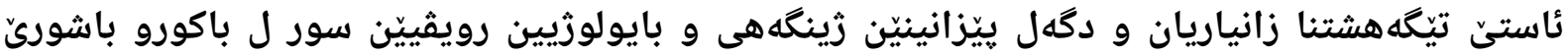
كومهلكهها شاريايه و زانينا يهيوهنديا گريّدايى ب خهلكى دهڤهرا دياركرى وهكو گوهوركى ياليشتيكار و

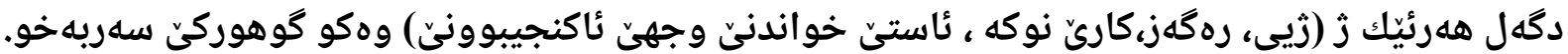

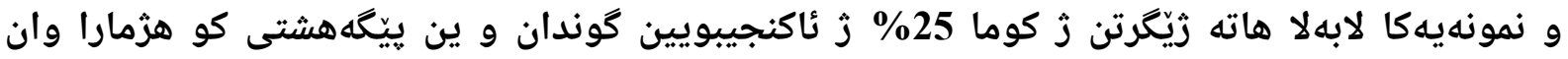

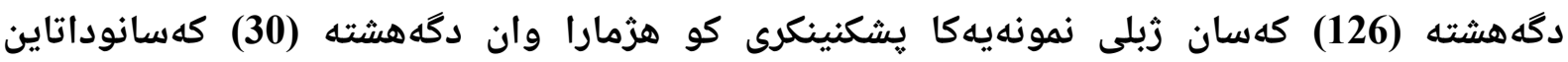

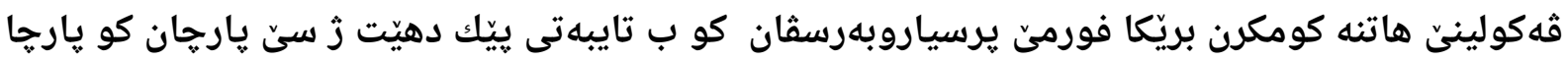

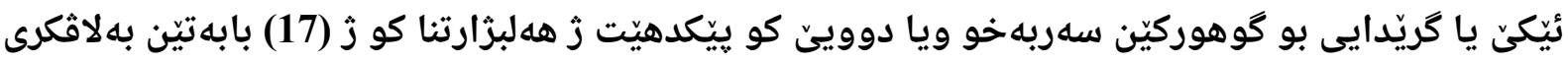

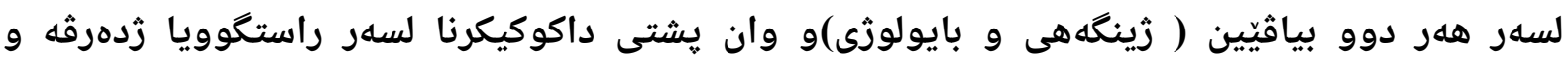

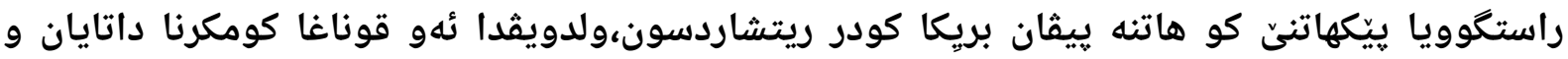


ثاله كرن، شروڤه كرن و جارهسهركرنا وان زلاييّ ئاماريڤه و بكارئينانا هزمارهكا ريّكيّن ئامارى ز كرنگترينيّن

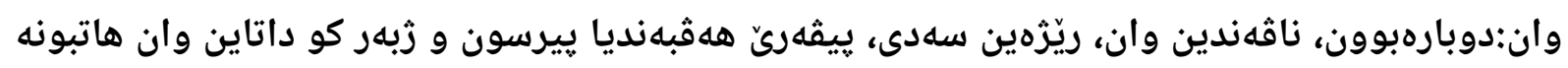

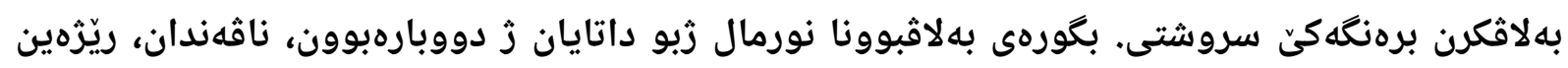

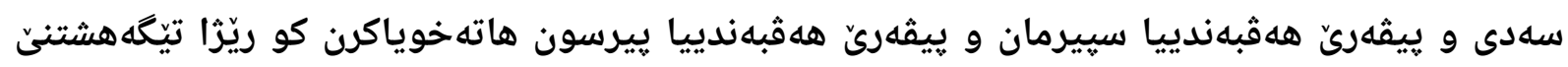

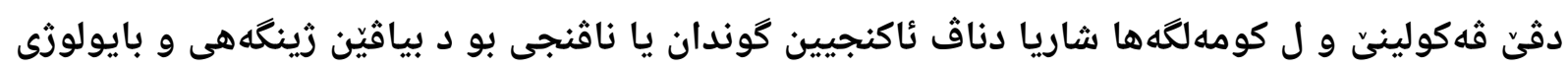

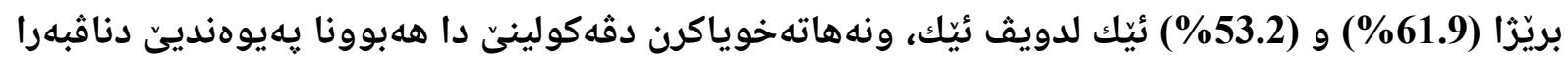

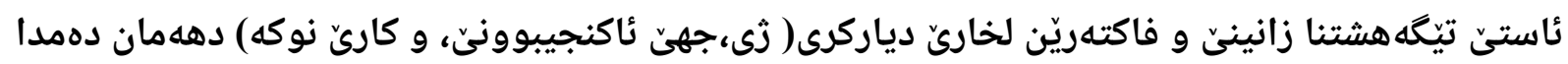

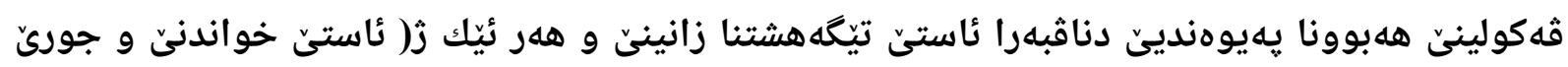
رهكهزى) دا دياركر.

المستوى المعرفي للسكان الريفيين بجوانب المعلومات البيئة والحيويةللثعالب الحمراء في مجمع شاريا

الخلاصة

ان الجماح عملية التنمية تتطلب تكامل مقوماتها من العناصر البشرية الواعية والدعم المادي. وبالنظر

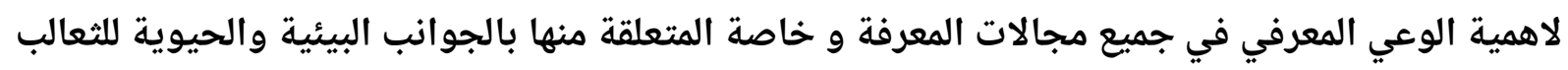
الحمراء والتي هي محور البحث. وذلك لتأثيرها الكبير على حقول المزارعين والسكان الريفيين. استهدف هذا البحث التعرف على مستوى الوعي المعرفي للسكان الريفيين الى جوانب المعلومات البيئية و الحيوية

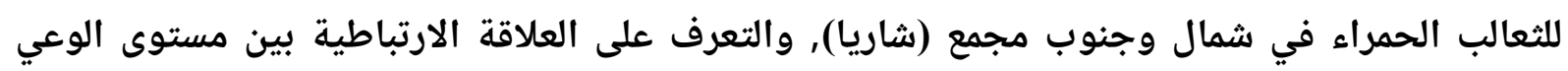

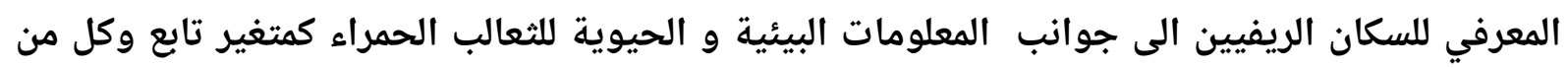
المتغيرات المستقلة (العمر, الجنس, المهنة الحالية, المستوى التعليمي, ومحل السكني). وتم اختيار عينة عشوائية بسيطة بواقع 25\% من السكان الريفيين والبالغ عددهم (126) باستثناء

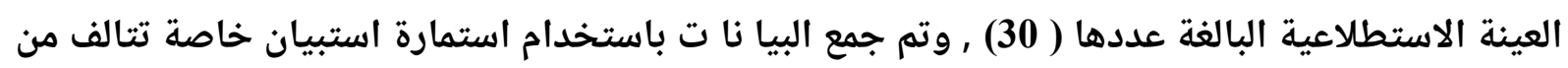

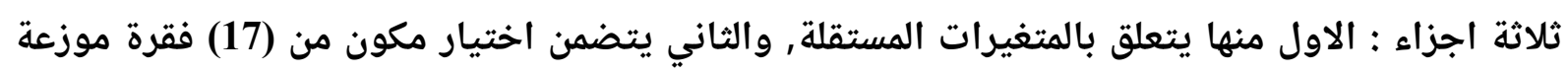

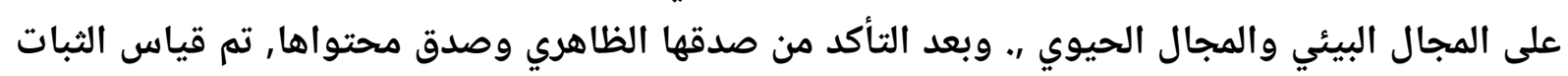
بطريقة كودر ريتشاردسون, ثم تلت تلك المرحلة جمع البيانات, تفريغها, تبويبها ومعالجتها احصائيا

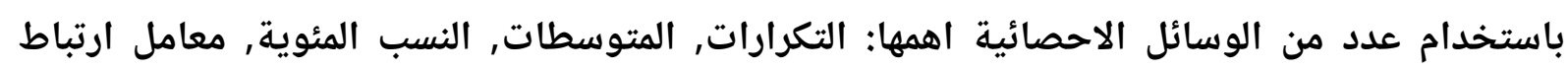
سبيرمان, ومعامل ارتباط بيرسون, وذلك لكون البيانات تتوزع طبيعياً. 